\title{
Yield of Aromatics from Naphthenics upon Catalytic Cracking
}

\author{
Richard A. Pujro, ${ }^{a}$ Marisa G. Falco, ${ }^{a}$ Anne M. Garrido Pedrosa, ${ }^{b}$ Marcelo J. B. Souza, ${ }^{c}$ \\ Edisson Morgado Jr. ${ }^{d}$ and Ulises Sedran*,a \\ anstituto de Investigaciones en Catálisis y Petroquímica INCAPE, \\ Universidad Nacional del Litoral - Consejo Nacional de Investigaciones Científicas y Técnicas, \\ Santiago del Estero 2654, 3000 Santa Fe, Argentina \\ ${ }^{b}$ Departamento de Química, Universidade Federal de Sergipe, 49100-000 São Cristovão-SE, Brazil \\ 'Departamento de Engenharia Química, Universidade Federal de Sergipe, \\ 49100-000 São Cristovão-SE, Brazil \\ ${ }^{d}$ Centro de Pesquisas e Desenvolvimento (CENPES), PETROBRAS S.A., Av. Horacio Macedo, 950, \\ Cidade Universitária, Ilha do Fundão, 21941-915 Rio de Janeiro-RJ, Brazil
}

\begin{abstract}
Cis- e trans decalina foram submetidas à reação com catalisadores de craqueamento, para estudar a formação de aromáticos numa fração particular de produtos líquidos do processo de craqueamento catalítico fluido (FCC). Um reator batelada em leito fluidizado, CREC, foi usado a 673 e $723 \mathrm{~K}$ com tempos de contato entre 3 e $15 \mathrm{~s}$. Cis-decalina foi muito mais reativa. Apesar de diferenças induzidas e medidas na acessibilidade dos catalisadores, seus perfis de atividade foram similares, sugerindo que restrições difusionais não prevalecem. Os produtos foram hidrocarbonetos $\mathrm{C}_{1}-\mathrm{C}_{12}$, enquanto o coque foi muito baixo. Reações de isomerização, craqueamento, transferência de hidrogênio, abertura/contração de anel e alquilação ocorreram, e produtos das várias reações foram observados em tempos de reação muito baixos. Naftênicos bicíclicos $\mathrm{C}_{10}$ e aromáticos alquilsubstituídos $\mathrm{C}_{7}-\mathrm{C}_{11}$ ou nafteno-aromáticos foram os produtos mais importantes. Um mecanismo de reação com três rotas iniciais (isomerização, abertura de anel e reações de transferência de hidrogênio) foi proposto.
\end{abstract}

\begin{abstract}
Cis- and trans-decalin were reacted over cracking catalysts to study the formation of aromatics in a particular fraction of the liquid products obtained in the fluid catalytic cracking process (FCC). A batch, fluidized bed CREC riser simulator reactor was used at 673 and $723 \mathrm{~K}$ and contact times varied from 3 to $15 \mathrm{~s}$. Cis-decalin was much more reactive. Despite differences induced and measured in their accessibility indices, the catalysts led to similar activity profiles, suggesting that diffusion restrictions do not prevail. Products were $C_{1}-C_{12}$ hydrocarbons while coke was very low. Isomerization, cracking, hydrogen transfer, ring opening, ring contraction and alkylation reactions occurred and products from the various reactions were observed at very short reaction times. Bicyclic $\mathrm{C}_{10}$ naphthenics and alkyl-substituted $\mathrm{C}_{7}-\mathrm{C}_{11}$ aromatics or naphtheno-aromatics were the most important products. A reaction mechanism with three initial routes (isomerization, ring opening and direct hydrogen transfer reactions) was proposed.
\end{abstract}

Keywords: aromatics, Y zeolite, decalin, cracking, hydrogen transfer

\section{Introduction}

The fluid catalytic cracking of hydrocarbons (FCC) is a key refining process that converts complex mixtures of lowvalue heavy hydrocarbons into high-value light products with high efficiency and integration with other process units in

*e-mail: usedran@fiq.unl.edu.ar the refinery. ${ }^{1}$ Liquefied petroleum gas (LPG), gasoline and middle distillates are among the most important products. The process can be considered mature, but demands to increase productivity, to process heavier, new or unconventional feedstocks, or to satisfy increasingly severe legislation about environmental care are clearly active. ${ }^{1}$

A neat worldwide trend to add more residual hydrocarbon cuts boiling over $803 \mathrm{~K}$ into vacuum gas 
oils (VGO), which are the typical feedstocks in FCC, can be observed, and at present technologies exist that can process full resid feedstocks. ${ }^{2}$ Resid FCC requires specific catalysts that could face much bulkier molecules, higher contaminant metal and heteroatoms contents and, particularly, higher coke yields. ${ }^{3}$ In those cases, it is clear that the diffusion of reactants and products, as well as the simultaneous adsorption processes, play a crucial role, and that the catalyst matrix and overall properties must ensure as good as possible a contact between hydrocarbons and catalytic surface. In order to characterize the catalyst properties in relation to these issues, an index presently named Albemarle accessibility index (AAI) ${ }^{4}$ which is aimed at describing how easy it is for reactant molecules to reach active sites, is used commercially.

Other issue of present interest concerning fuel production in FCC is the composition of the light cycle oil (LCO, middle distillate) cut, usually defined between about 453 and $623 \mathrm{~K}$ boiling points, which can be used as a contributor to the diesel fuel pool together with streams from other processes such as topping, hydrocracking, coking and visbreaking. ${ }^{5}$ Since the quality of diesel fuel depends strongly on the amount of paraffins, the problem in LCO as a contributor to the diesel pool is that it has a high concentration of aromatic compounds, between 50 and 70\%; such a high content depends on the source crude oil, the type of catalyst used and the process conditions. ${ }^{5}$ It is in this scene that opportunities exist to generate new catalysts to produce less aromatics in FCC, probably diverting from conventional Y zeolite, thus making it necessary to know about the mechanisms of aromatics formation in the LCO range. Aromatics may be formed directly by cracking of side chains in heavy aromatic molecules in the feedstock, or by secondary hydrogen transfer reactions after olefin cyclization in the complex network of chemical reactions in FCC. ${ }^{6,7}$

The reaction of model compounds may help to understand mechanistic and accessibility issues. For example, bulky molecules such as tri-isopropylbenzene were used to test accessibility in commercial FCC catalysts and in aluminas used as FCC catalyst matrix, showing that a direct relationship exists between alumina activity and mean pore size and accessibility in those matrices. ${ }^{8}$ Decahydronaphthalene (decalin) is a naphthenic compound in the low boiling range of LCO, with two isomeric forms, cis- and trans-decalin. In this work the primary potential of decalin as a test reactant in particular relation to aromatics formation and catalyst accessibility in FCC was evaluated with three catalysts having different accessibility index, other properties such as zeolite content and unit cell size being the same. The reactor used was a CREC Riser Simulator laboratory unit, which closely mimics the conditions of the FCC process.

\section{Experimental}

The three catalysts used were prepared in pilot plant scale using RE-USY zeolite, silica, alumina and clay as ingredients, following the technique to improve accessibility described in the patent literature. ${ }^{9}$ Before catalytic testing, they were steamed at $1061 \mathrm{~K}$ for $5 \mathrm{~h}$ in order to simulate the hydrothermal deactivation experienced by the catalyst in a commercial FCC regenerator. The main properties of the deactivated catalysts are shown in Table 1. The most important difference among catalysts was the accessibility parameter, as expressed by the AAI index, while the unit cell size (UCS) of the zeolite component and the zeolite load on the catalysts (average 17\%) were the same. The samples were designed following their accessibility as low (LA), medium (MA), and high (HA) accessibility catalysts, respectively.

The assessment of specific surface areas (BET and t-plot methods) was performed with $\mathrm{N}_{2}$ isotherms at 77 K. UCS's were determined with the ASTM D-3942-91 $\mathrm{X}$-ray diffraction technique. AAI was assessed by means of the method described by Hakuli et al. ${ }^{4}$ The AAI test measures the liquid phase diffusion of large organic molecules (asphaltenes) into the catalyst by means of an UV spectrometer, by tracking the relative concentration of the molecules that adsorb at certain wavelength as a function of time, and the faster the evolution, the higher the index and the accessibility in the catalyst. ${ }^{4}$ AAI defines an overall property.

The experiments of conversion of decalin (SigmaAldrich $\mathrm{C}_{10} \mathrm{H}_{18}, \geq 99 \%$, cis- and trans-decahydronaphthalene isomers mixture) were performed in a CREC Riser Simulator laboratory reactor, ${ }^{10}$ designed to simulate FCC

Table 1. Properties of the catalysts used

\begin{tabular}{|c|c|c|c|c|c|c|c|}
\hline \multirow{2}{*}{ Catalyst } & \multirow{2}{*}{ AAI } & \multirow{2}{*}{$\begin{array}{l}\text { Zeolite UCS / } \\
\text { nm }\end{array}$} & \multirow{2}{*}{ Zeolite load / \% } & \multirow{2}{*}{$\begin{array}{c}\text { RE oxide } \\
\text { content / \% }\end{array}$} & \multicolumn{2}{|c|}{ Specific surface area $/\left(\mathrm{m}^{2} \mathrm{~g}^{-1}\right)$} & \multirow{2}{*}{$\begin{array}{l}\text { Average pore } \\
\text { diameter / nm }\end{array}$} \\
\hline & & & & & Matrix & Total & \\
\hline LA & 11 & 2.428 & 16 & 1.33 & 58 & 165 & 3.1 \\
\hline MA & 14 & 2.428 & 18 & 1.26 & 50 & 172 & 2.9 \\
\hline HA & 20 & 2.428 & 17 & 1.37 & 70 & 184 & 2.8 \\
\hline
\end{tabular}


process conditions. The reactor has a turbine on top of a chamber that holds the catalyst bed between two porous metal plates. The turbine rotates at $7500 \mathrm{rpm}$, inducing a low pressure area in the upper central zone in the reactor that makes gases circulate in the upwards direction through the chamber, thus fluidizing the catalyst bed. When the reactor is at the desired experimental conditions, the liquid reactant is fed with a syringe through an injection port and vaporizes instantly, thus setting the initial reaction time. After the desired reaction time is reached, the gaseous mixture is evacuated immediately and products can be sent to analysis. Additional descriptive details can be found in the literature. ${ }^{11}$

Reaction times in the experiments were from 3 to $15 \mathrm{~s}$, and temperatures were 673 and $723 \mathrm{~K}$, with a mass catalyst to oil relationship $(\mathrm{C} / \mathrm{O})$ of 2.23 and a catalyst mass of $0.4 \mathrm{~g}$. Experiments of purely thermal cracking, with no catalyst in the reactor, were performed at the same temperatures and the longest residence time, $15 \mathrm{~s}$. Mass balances closed to more than $94 \%$ in all the cases.

Reaction products were analyzed by means of conventional capillary gas chromatography, with on-line sampling and injection on a $30 \mathrm{~m}, 0.25 \mathrm{~mm}$ i.d. and $0.25 \mu \mathrm{m}$ phase thickness, non polar HP-1 column. The relationship between isomers in decalin was analysed similarly. Coke was determined by means of a temperature programmed oxidation procedure; carbon oxides from the combustion were immediately transformed into methane over a $\mathrm{Ni}$ catalyst and quantified with the help of a FID detector.

\section{Results and Discussion}

The properties of the catalysts used are shown in Table 1. The steam deactivated catalysts have AAI values in the upper range of those shown by equilibrium commercial catalysts. In fact, accessibility of catalysts that were severely steamed in the laboratory tends to be higher than that of the corresponding equilibrium catalyst, which appears to be associated with the formation of microcracks on the outer surface of the deactivated catalyst particles. Deposition of metal contaminants tends to decrease the accessibility relative to the steamed catalysts; however, the reduced accessibilities typical of equilibrium catalysts are never achieved in most of the routine lab-scale deactivation methods. ${ }^{4,12}$ For this reason, the distinct accessibilities obtained for the three samples, and thus the effective diffusion of hydrocarbons into the compound pore structures, should be considered on a relative basis. The other physical properties are in the range of typical regenerated equilibrium FCC catalysts and particularly the UCS, the average pore diameter and the zeolite load should be considered as effectively being the same in all the samples.

The concentrations of trans- and cis- isomers in the reactant were 48 and 52\%, respectively. The cis-isomer was more reactive than the trans-isomer over all the catalysts at both temperatures, as shown in Figure 1. In effect, it can be seen that the concentration profiles for cis-decalin decrease strongly and steadily as a function of reaction time, while those of trans-decalin show either a slightly increasing profile at the lowest reaction temperature of $673 \mathrm{~K}$, or a slow decrease at $723 \mathrm{~K}$. These different behaviors between the cis- and the trans- isomers were also observed by other authors. For example, Lai and Song ${ }^{13}$ and Kubicka et al. ${ }^{14}$ who studied the conversion of decalin over different zeolites at lower temperatures, from 473 to $573 \mathrm{~K}$, reported similar results on pure Y zeolite. A study performed by Mostad et al. ${ }^{15}$ with a wider temperature range (603 to $733 \mathrm{~K}$ ) over various zeolites, showed that if the reactant was cis-, trans- or a mixture of both isomers over Y zeolite at 603 or $665 \mathrm{~K}$, the only product was trans-decalin and concluded that cis-decalin stereoisomerizes into trans-decalin; at $733 \mathrm{~K}$ they found that cis-decalin appeared in the products from trans-decalin conversion, but, more interestingly, they determined that the rate of cis- to trans- isomerization was about 6 to 10 times faster than the trans- to cis- isomerization. Moreover, and considering that the products from the conversion of both pure isomers were the same, they determined that the conversion of cis-decalin into other products was $10^{5}$ times faster than that of trans-decalin.

The much higher reactivity of cis-decalin could be rationalized on the fact that the space configurations of the

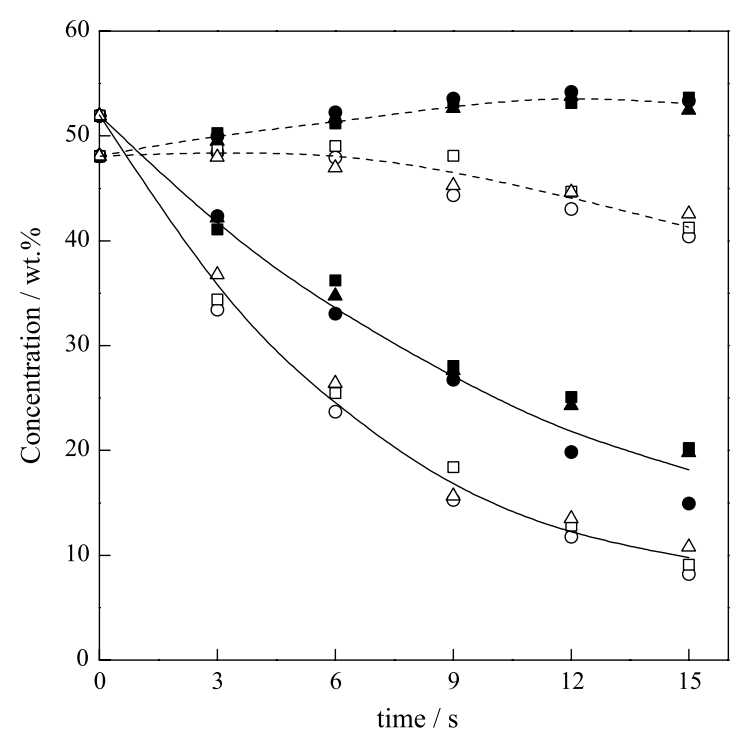

Figure 1. Concentration of the two decalin isomers as a function of reaction time. Lines: solid, cis-decalin; dashed, trans-decalin. Symbols, catalysts: • LA; $\mathbf{M A}$; HA; closed, $673 \mathrm{~K}$; open, $723 \mathrm{~K}$. 
isomers are different; in effect, the cis-isomer is slightly smaller $(0.56 \times 0.67 \times 0.88 \mathrm{~nm})$ and less stable and rigid than the trans- form $(0.52 \times 0.76 \times 1.00 \mathrm{~nm}) .{ }^{15}$ It can be seen in the comparison with cyclohexane in Figure 2 that in the proposed configuration of cis-decalin, the second six-atom ring is built on an equatorial bond and an axial bond in the first ring ${ }^{16}$ this bond suffering van der Waals repulsion through 1,3 diaxial interactions. In the case of transdecalin, the second ring is constructed on two equatorial bonds in the first ring. However, Y zeolite cavities are large enough to accommodate these molecules similarly, ${ }^{15}$ and no significant restrictions to diffusion are to be expected in the zeolite structure.

Santikunaporn et al. ${ }^{17}$ used a mixture of both isomers and reported a fast conversion of the cis-isomer with a minor formation of the trans-isomer at $533 \mathrm{~K}$ and short space times over Y zeolite, the other products being mostly $\mathrm{C}_{10}$ molecules after isomerization and ring opening and contraction reactions. Sousa-Aguiar et al., ${ }^{18}$ who used a mixture of the isomers over deuterated zeolites, also identified cis-decalin as the most reactive, and suggested that the reaction is initiated by means of a nucleophilic attack by the zeolite protons on the tertiary carbons in decalin, which are more exposed in the cis-isomer (see Figure 2).

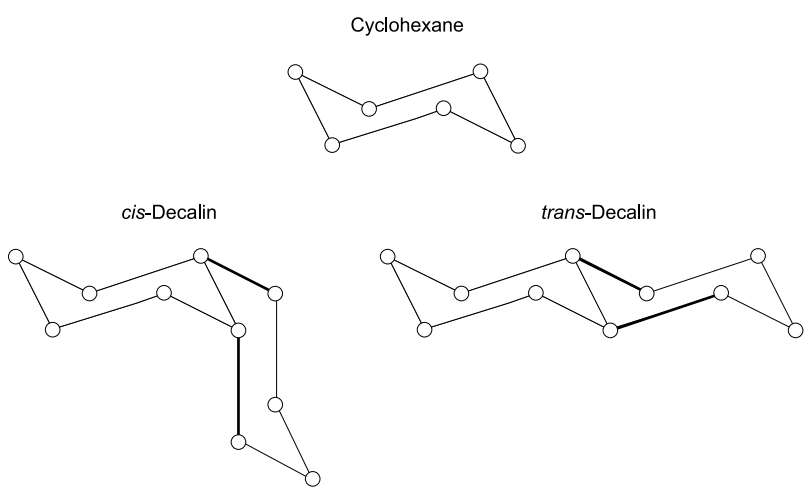

Figure 2. Space configuration of decalin isomers. From reference 16.

The additions of the conversions of both isomers in the thermal cracking experiments, at the longest residence time of $15 \mathrm{~s}$ and highest temperature of $723 \mathrm{~K}$, were lower than $2.47 \%$; in this way the impact of thermal cracking was considered negligible as compared to conversion provided by the catalysts. These results are consistent with previous observations from Al-Sabawi and de Lasa ${ }^{19}$ at the same temperature. The effect of the very low metal area provided by the reactor and catalyst support plates should be disregarded.

The previous considerations allow regarding decalin as a single species in the forthcoming yield analysis. It can be seen in Figure 3 that the catalysts studied showed very similar conversion profiles as a function of reaction time at each temperature. In support of this observation, two particular facts about the formulation of these catalysts should be considered. First, the most important catalyst component, the $\mathrm{Y}$ zeolite, is present with essentially the same amount in all the catalysts (see Table 1). Second, the UCS in the Y zeolite, which can be related to the concentration of aluminum atoms and, consequently, to the number of acid sites and catalyst activity, is the same in all the cases (24.28 $\AA$ ). Matrix components (silicaalumina based) and their compositions were exactly the same for the three catalysts, so that only mesopore architecture and accessibility were modified by controlling the compounding conditions.

The catalysts physical properties can not be correlated with the observations about activity. Moreover, the different accessibilities in each of the catalysts do not reflect on the conversion profiles, suggesting that the reactant molecules do not suffer diffusion restrictions in the compound catalysts in any case, and would convert essentially on the zeolite, a fact which is in line with the previous discussion about the configurations of the reactant molecules. Since the catalysts studied only differ in accessibility properties, it can be stated that, for the range of values studied and experimental conditions, those properties did not impact on the performance of the catalysts.

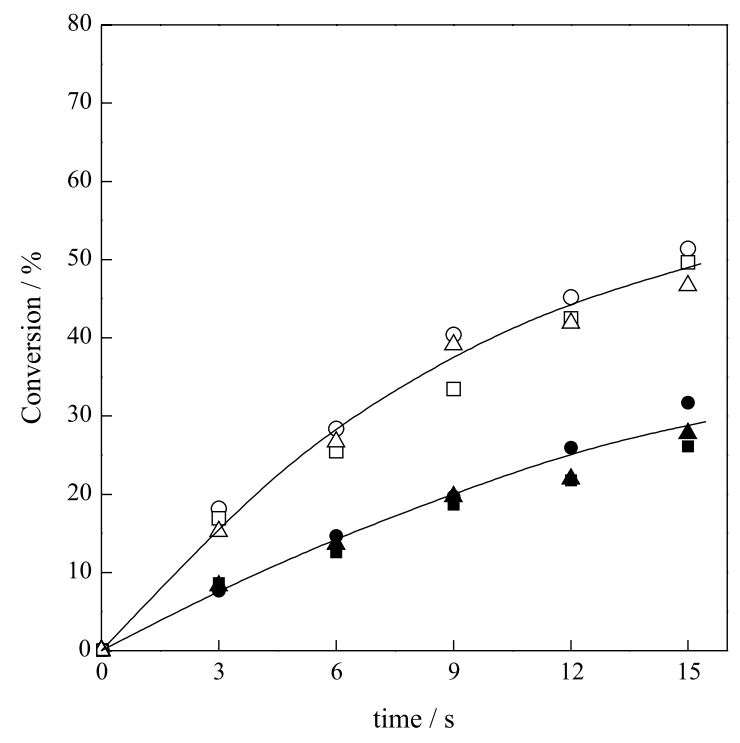

Figure 3. Conversion of decalin as a function of reaction time. Symbols, catalysts: $(\bullet)$ LA; (•) MA; (ム) HA; closed, $673 \mathrm{~K}$; open, $723 \mathrm{~K}$.

Reaction products in the conversion of decalin over the laboratory catalysts extended to a very complex set of compounds from $\mathrm{C}_{1}$ to $\mathrm{C}_{12}$ hydrocarbon molecules, including linear and cyclic olefins and paraffins, bicyclic 
naphthenes, naphtheno-aromatics, and alkylated aromatics and diaromatics. An example of the product distributions obtained with the different catalysts at $723 \mathrm{~K}$ is shown in Table 2. These products are consistent with the proposed mechanisms for decalin reaction on acidic catalysts ${ }^{14,17,19,20}$ and could be arbitrarily grouped as representative of the main reactions.

According to the observed product yields, most important reactions are those of isomerization, cracking, hydrogen transfer, ring contraction, ring opening and, to a lower extent, alkylation. These definitions do not imply a sequential order and do not exclude other possible reactions, but they are an attempt to show major facts in decalin conversion as the consequence of catalyst properties and reaction conditions. Isomerization is represented by bicyclic $\mathrm{C}_{10}$ compounds (mainly dimethyl octabicyclic); cracking reactions by $\mathrm{C}_{1}-\mathrm{C}_{9}$ compounds (olefins, paraffins, naphthenes, naphthenoaromatics and aromatics); direct hydrogen transfer by naphthalene and tetralin; direct ring opening reactions by $\mathrm{C}_{10}$ alkylated naphthenes and cyclic olefins (such as isobutyl cyclohexane and 3-butyl cyclohexene, respectively); ring contraction by indane-type compounds and alkylation reactions can be particularly represented by the yield of $\mathrm{C}_{11}-\mathrm{C}_{12}$ alkylated aromatics or naphthenic-aromatics, such as methylnaphthalene and methyltetralin.

The initial reactions of decalin conversion on acidic catalysts were focused on isomerization or ring opening. For example, at the temperature of $723 \mathrm{~K}$, it was inferred that the first step of the conversion of decalin on $\mathrm{Y}$ zeolite is the ring opening to yield a butyl cyclohexyl carbenium ion, which can desorb as butylcyclohexene or $\beta$-crack into lighter hydrocarbons. ${ }^{19,20}$ When the reaction was performed at lower temperatures (498 to $600 \mathrm{~K}$ ), higher pressures and with some hydrogen present, it was reported that isomerization products were primary and ring opening products were secondary in the reaction scheme..$^{14,20}$ However, it was observed in the present work that various products representative of different possible reactions do show at very low reaction times and conversions, thus giving support to the view that reactions such as cracking, ring opening, ring contraction, isomerization and hydrogen transfer, are present initially in a significant proportion. Moreover, some of the reactions can be assigned a secondary role too. For example, hydrogen transfer can proceed after ring opening and cracking of isomers to produce alkyl naphthenes or cyclic olefins, to yield aromatics; or ring opening can follow after direct hydrogen transfer from decalin to tetralin, to yield polysubstituted aromatics.

Figure 4 shows the yield curves of isomerization, cracking, hydrogen transfer, ring contraction, ring
Table 2. Product yields (wt.\%) in decalin conversion (average 16\%). C/O: 2.23. Temperature: $723 \mathrm{~K}$

\begin{tabular}{|c|c|c|c|}
\hline \multirow[b]{2}{*}{ Products } & \multicolumn{3}{|c|}{ Catalyst } \\
\hline & LA & MA & HA \\
\hline $\mathrm{C}_{1}-\mathrm{C}_{2}$ & 0.03 & 0.03 & 0.02 \\
\hline $\mathrm{C}_{3}$ & 0.24 & 0.24 & 0.31 \\
\hline $\mathrm{C}_{4}$ olefins & 0.12 & 0.11 & 0.10 \\
\hline $\mathrm{C}_{4}$ paraffins & 0.75 & 0.72 & 0.64 \\
\hline $\mathrm{C}_{5}$ olefins & 0.02 & 0.03 & 0.04 \\
\hline $\mathrm{C}_{5}$ cyclo olefins & 0.03 & 0.03 & 0.02 \\
\hline $\mathrm{C}_{5}$ paraffins & 0.29 & 0.28 & 0.25 \\
\hline $\mathrm{C}_{5}$ cyclo paraffins & 0.08 & 0.08 & 0.07 \\
\hline $\mathrm{C}_{6}$ olefin & 0.02 & 0.02 & 0.02 \\
\hline $\mathrm{C}_{6}$ paraffins & 0.20 & 0.19 & 0.18 \\
\hline $\mathrm{C}_{6}$ naphthenes & 0.83 & 0.77 & 0.71 \\
\hline Benzene & 0.04 & 0.05 & 0.04 \\
\hline $\mathrm{C}_{7}$ cyclo olefins & 0.01 & 0.01 & 0.01 \\
\hline $\mathrm{C}_{7}$ paraffins & 0.06 & 0.05 & 0.05 \\
\hline $\mathrm{C}_{7}$ naphthenes & 0.58 & 0.52 & 0.50 \\
\hline Toluene & 0.07 & 0.08 & 0.06 \\
\hline $\mathrm{C}_{8}$ paraffins & 0.04 & 0.04 & 0.04 \\
\hline $\mathrm{C}_{8}$ naphthenes & 0.23 & 0.19 & 0.21 \\
\hline $\mathrm{C}_{8}$ aromatics & 0.07 & 0.11 & 0.05 \\
\hline $\mathrm{C}_{9}$ paraffins & 0.03 & 0.02 & 0.03 \\
\hline $\mathrm{C}_{9}$ naphthenes & 0.08 & 0.04 & 0.07 \\
\hline $\mathrm{C}_{9}$ aromatics & 0.55 & 0.49 & 0.44 \\
\hline $\mathrm{C}_{9}$ naphtheno-aromatics & 0.83 & 0.77 & 0.65 \\
\hline trans-Decalin & 48.39 & 48.68 & 47.99 \\
\hline cis-Decalin & 33.44 & 34.42 & 36.76 \\
\hline Isobutyl cyclo $\mathrm{C}_{6}$ & 0.28 & 0.25 & 0.23 \\
\hline 3-butyl cyclo $\mathrm{C}_{6}$ olefin & 0.28 & 0.25 & 0.23 \\
\hline $\mathrm{C}_{10}$ aromatics & 2.89 & 2.87 & 2.50 \\
\hline Naphthalene & 0.53 & 0.32 & 0.47 \\
\hline $\mathrm{C}_{10}$ naphtheno-aromatics & 0.56 & 0.58 & 0.57 \\
\hline Tetralin & 0.61 & 0.48 & 0.60 \\
\hline 1,1’́bicyclo C5 & 0.00 & 0.00 & 0.00 \\
\hline Trimethyl bicyclo $\mathrm{C}_{7}$ & 0.73 & 0.63 & 0.60 \\
\hline Dimethyl bicyclo $\mathrm{C}_{8}$ & 6.32 & 5.89 & 4.85 \\
\hline $\mathrm{C}_{11}$ aromatics & 0.02 & 0.02 & 0.02 \\
\hline Methyl naphthalene & 0.01 & 0.01 & 0.01 \\
\hline $\mathrm{C}_{11}$ naphtheno-aromatics & 0.02 & 0.03 & 0.03 \\
\hline $\mathrm{C}_{12}{ }^{+}$aromatics & 0.00 & 0.00 & 0.00 \\
\hline $\mathrm{C}_{12}{ }^{+}$naphtheno-aromatics & 0.00 & 0.01 & 0.02 \\
\hline Coke & 0.25 & 0.20 & 0.33 \\
\hline
\end{tabular}


opening and alkylation products at 673 and $723 \mathrm{~K}$ for the example of catalyst LA, although the same behaviour could be observed on the other catalysts, suggesting that the overall reaction paths are the same independently of the differences between catalysts. It can be seen that all the products showed an essentially primary character, with the exception of alkylation products, which are secondary and clearly require firstly the production of aromatics to proceed. Cracking products could also be assigned a primary plus secondary character, particularly at $723 \mathrm{~K}$. Isomerization and hydrogen transfer products showed an unstable profile, thus suggesting that decalin isomers could be subjected to ring opening and cracking reactions. The low yield of direct ring opening products can be associated to the high reactivity of the intermediary butyl cyclohexyl carbenium ion, particularly leading to cracking products. Ring contraction products, which are represented by compounds of the indane family, showed a higher yield than the previous group and suggest a higher stability.

Quintana-Solórzano et al. ${ }^{21}$ studied the behavior of $n$-butyl cyclohexane, a product that can be considered to be one of the first after hydride transfer to a butyl cyclohexyl carbenium ion from the initial opening of one of the naphthenic rings in decalin, at $723 \mathrm{~K}$ over rare earth containing, ultrastable $\mathrm{Y}$ zeolite; they found products $\left(\mathrm{C}_{3}-\right.$ $\mathrm{C}_{5}$ paraffins and olefins) that came from both the cracking of the side chain and the naphthenic ring in $n$-butyl cyclohexane, but, however, they did not report $\mathrm{C}_{10}$ isomers of any type among products.

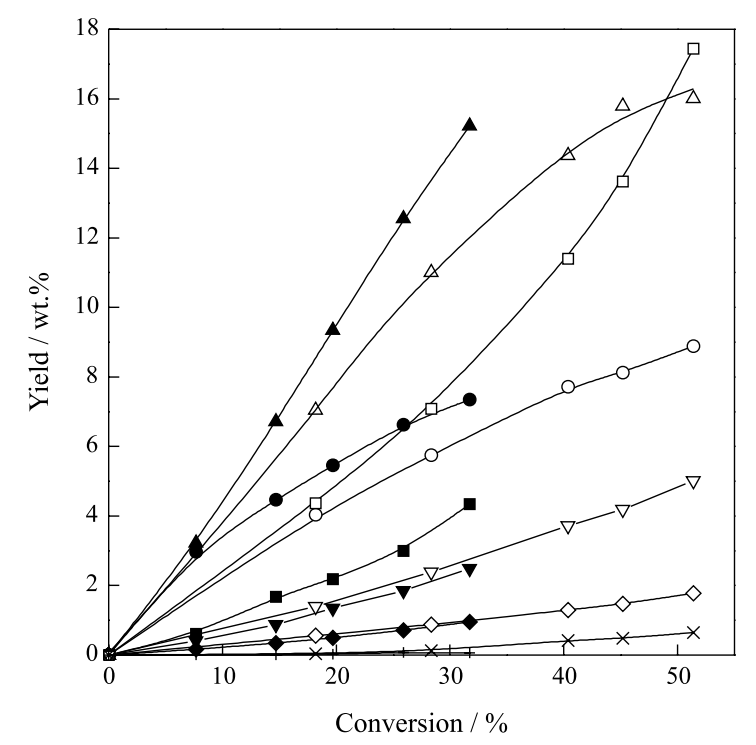

Figure 4. Yields of the various reaction products as a function of conversion. Catalyst LA. Symbols: (A) isomerization, (ם) cracking, $(\bullet)$ hydrogen transfer, $(\boldsymbol{\nabla})$ ring contraction, $(\bullet)$ ring opening, $(\times)$ alkylation; closed, $673 \mathrm{~K}$; open, $723 \mathrm{~K}$.
The impact of temperature is different on the various reactions. Overall, from the comparison of the results at both reaction temperatures (see Figure 4), the cracking reactions show a higher thermal sensitivity, as compared to hydrogen transfer and isomerization, which showed a decrease in the yield curves. These facts are consistent with previous observations about the relative thermal sensitivities of these reactions. ${ }^{22}$ Ring contraction reactions showed a very small increase in yield as reaction temperature changed from 673 to $723 \mathrm{~K}$, and ring opening reactions did not change its yield.

In particular relation to the formation of aromatic compounds, it is well known that cracking naphthenic compounds over zeolites yields significant amounts of aromatic hydrocarbons. ${ }^{23}$ In coincidence, aromatic selectivities of $35 \%$ and initial molar selectivities of $0.791^{20}$ were reported among products in the conversion of decalin over zeolitic catalysts at high reaction temperatures from 723 to $823 \mathrm{~K}$. Other authors found very low yields, possibly due to the low reaction temperatures, below $623 \mathrm{~K}$, or to the co-feeding of hydrogen in the reaction medium that might saturate intermediate olefins. ${ }^{14,17}$ Hydrogen transfer was suggested a major reaction at temperatures higher than $623 \mathrm{~K}$, leading to up to $40 \%$ of aromatics in the conversion of decalin over acidic catalysts loaded with metals such as Pt or Ir. ${ }^{24}$

The impact of hydrogen transfer on aromatic yields was underlined by Sousa-Aguiar et al., ${ }^{18}$ who associated the low concentration of olefins in the reaction medium to their consumption through these reactions, where naphthenes may play a donor role and convert themselves into aromatics. ${ }^{25}$ In this work, aromatics were observed in high proportions at $723 \mathrm{~K}$, being, for example, up to $36 \%$ of the products in the case of including naphtheno-aromatic hydrocarbons (see Table 2). In opposition, olefins were observed in small amounts. Figure 5 shows the yield curves of the aromatic hydrocarbons for the example of catalyst LA, grouped according to the number of carbon atoms in their molecules. It can be seen that $\mathrm{C}_{10}$ aromatics, that is, with the same number of carbon atoms per molecule as decalin, and including tetralin and naphthalene, which are formed directly by hydrogen transfer from decalin, are the most important group. These compounds are primary and show a slightly unstable character, probably supporting alkylation to yield $\mathrm{C}_{11}{ }^{+}$aromatics, which are secondary products. Ring opening reactions from decalin and isomers and further hydrogen transfer may also contribute to $\mathrm{C}_{10}$ aromatics. The $\mathrm{C}_{6}-\mathrm{C}_{9}$ group, which includes products from the ring opening of decalin and isomers, followed by cracking and hydrogen transfer reactions, was the second most important among aromatics. The group shows a very 
slightly secondary character. Finally, the yield of $\mathrm{C}_{11}{ }^{+}$ aromatic hydrocarbons, after alkylation, is small, and the expectable secondary character of these hydrocarbons can be seen more clearly at $723 \mathrm{~K}$.

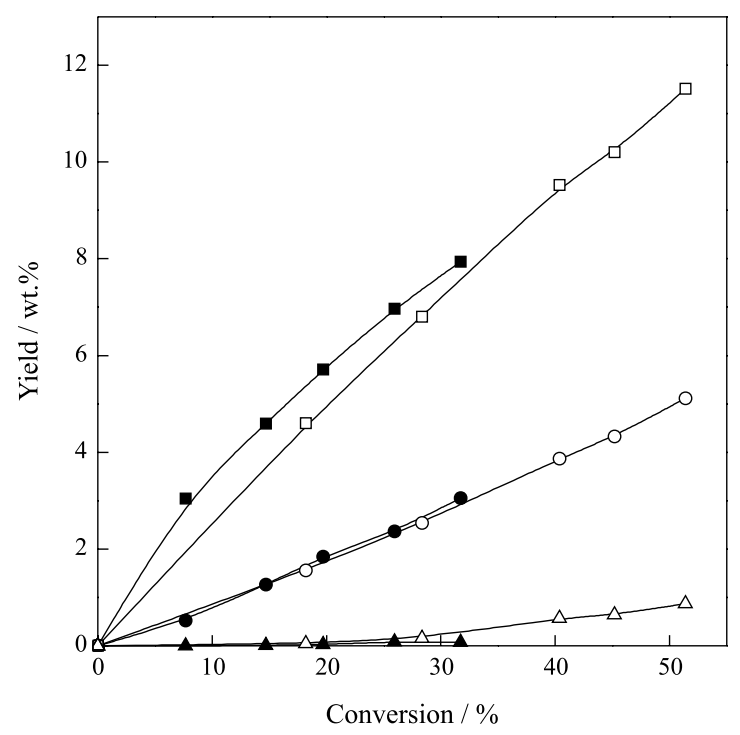

Figure 5. Yields of aromatics compounds as a function of conversion. Symbols: $(\bullet) \mathrm{C}_{6}-\mathrm{C}_{9},(\bullet) \mathrm{C}_{10},(\Delta) \mathrm{C}_{11}{ }^{+}$; closed, $673 \mathrm{~K}$; open, $723 \mathrm{~K}$.

The yield curves of the $\mathrm{C}_{6}-\mathrm{C}_{9}$ group are shown in Figures $6 \mathrm{a}$ and $6 \mathrm{~b}$, the most important products being indane and $\mathrm{C}_{9}$ alkyl aromatics. The $\mathrm{C}_{10}$ group of aromatic compounds can be observed in Figures $6 \mathrm{c}$ and $6 \mathrm{~d}$; most important products are alkylated monoaromatics, which showed an unstable character at high conversion. $\mathrm{C}_{10}$ naphtheno-aromatics, such as methyl indane, showed to be secondary products and were particularly sensitive to reaction temperature, increasing their production significantly. Finally, the secondary character of $\mathrm{C}_{11}{ }^{+}$aromatics, mostly alkylated diaromatics and naphtheno-aromatics is clearly shown in Figures $6 e$ and $6 f$.

According to the evolution of the concentration of the various aromatic compounds, it can be concluded that most important aromatic or naphtheno-aromatic products from the conversion of decalin have one aromatic ring with some degree of substitution, mainly in the $\mathrm{C}_{9}-\mathrm{C}_{10}$ range and, to a lower extent, they are aromatics with two benzenic rings.

The impact of reaction temperature on the distribution of aromatic products can be observed in Figure 6 (catalyst LA) at a given conversion, e.g., 20\%. Qualitatively similar results were obtained with the other catalysts. While it was shown in Figure 5 that the $\mathrm{C}_{6}-\mathrm{C}_{9}$ group maintained their yields, indeed the $\mathrm{C}_{9}$ naphtheno-aromatics and alkyl aromatics decreased and the lighter compounds in the group, such as benzene, toluene and xylene increased. The effect was more significant on $\mathrm{C}_{10}$ alkyl aromatics, which decreased their yield in about $40 \%$ from $673 \mathrm{~K}$ to $723 \mathrm{~K}$; methyl indane increased and naphthalene decreased slightly, probably sustaining alkylation reactions. The increase in $\mathrm{C}_{11}{ }^{+}$naphtheno-aromatics and $\mathrm{C}_{12}{ }^{+}$alkyl aromatics is important in relative terms. All these variations can be explained based on a relatively more important occurrence of cracking of side chains, ring opening and alkylation reactions, and support the view that they are favored against hydrogen transfer reactions when temperature is increased. ${ }^{22}$

Then, with basis in these results and previous reports, ${ }^{14,17,19-21}$ it is possible to postulate a new set of overall reaction paths, which is shown in Figure 7. As shown by the yield curves in Figure 4, direct and subsequent hydrogen transfer would constitute an important set of reactions from the beginning of the reaction system. Cracking reactions leading to olefins, paraffins, and naphthenes lighter than decalin require previous ring opening reactions. These ring opening reactions (indeed cracking reactions) are usually referred to the aperture of one of the rings in decalin or other two-ring naphthenes. ${ }^{19,20,26,27}$ Isomerization reactions imply either contraction or expansion of the rings in decalin, leading to hydrocarbons with two alkylated fused rings; further cracking of these compounds may originate lighter olefins, paraffins, and naphthenes, and be also the source for polyalkylated $\mathrm{C}_{5}$ or $\mathrm{C}_{6}$ naphthenes.

The products from the initial set of isomerization, ring opening and direct hydrogen transfer reactions can be subjected to a number of additional reactions. The products from direct hydrogen transfer from decalin, such as tetralin and naphthalene, may suffer from ring contraction for the production of indane or alkyl indane compounds, or ring opening leading to polyalkylated $\mathrm{C}_{10}$ aromatics or, to a lower degree, to alkylation to heavy compounds. Additional sources for aromatics can be easily envisaged in Figure 7.

In relation to the formation of aromatic hydrocarbons, then, it can be stated that all the three initial routes could contribute to them (refer to Figure 7), although the most direct route would be that of direct hydrogen transfer from decalin to form naphthalene and tetralin, which could be further subjected to ring contraction, ring opening and alkylation reactions to yield different types of napthenicaromatic and aromatic compounds. The other routes, which would only contribute to alkylated monoaromatics, imply more steps. The most prevailing aromatics are those with the same number of $\mathrm{C}$ atoms as the reactant decalin (see Figure 5), suggesting that under the conditions tested it is not easy to directly open the second naphthenic ring, since long chain paraffins or olefins were not observed in significant amounts at any extent of the whole reaction. The conversion scheme of decalin or similar hydrocarbons 

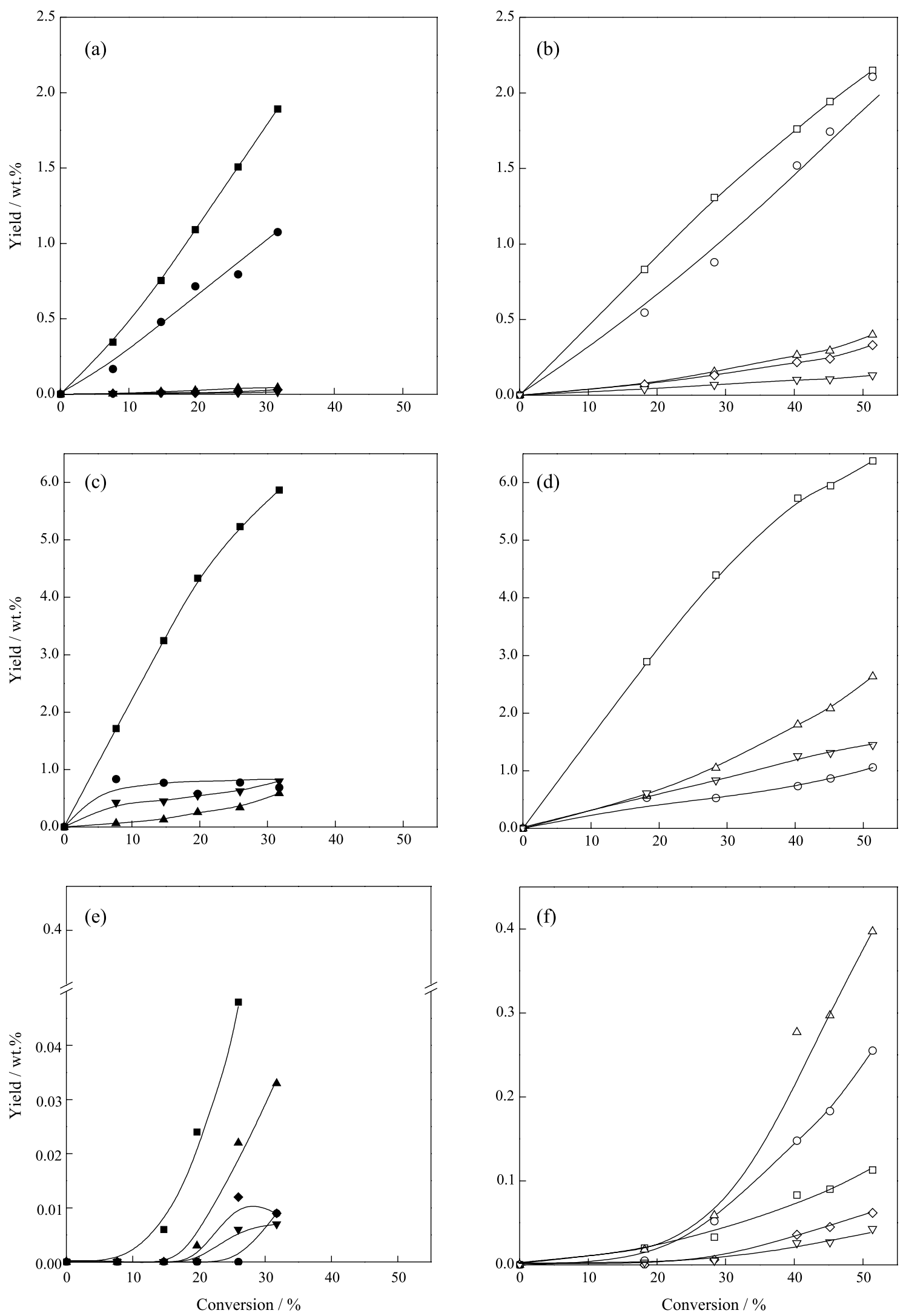

Figure 6. Yield curves of aromatic compounds. Closed symbols, $673 \mathrm{~K}$; open symbols, $723 \mathrm{~K}$. (a) and (b), aromatics $\mathrm{C}_{6}-\mathrm{C}_{9}$ : $(\mathbf{\square}, \square) \mathrm{C}_{9}$ naphtenic-aromatics, $(\bullet, \bigcirc) \mathrm{C}_{9}$ aromatics, $(\boldsymbol{\Lambda}, \triangle) \mathrm{C}_{8}$ aromatics, $(\bullet, \diamond)$ toluene, $(\mathbf{\nabla}, \nabla)$ benzene. (c) and (d), aromatics $\mathrm{C}_{10}:(\boldsymbol{\bullet}, \square) \mathrm{C}_{10}$ aromatics, $(\bullet, 0)$ naphtalene, $(\mathbf{\nabla}, \nabla)$ tetralin, $(\boldsymbol{\Delta}, \triangle) \mathrm{C}_{10}$ naphtenic-aromatics. (e) and (f), aromatics $\mathrm{C}_{11}{ }^{+}:(\mathbf{\square}, \square) \mathrm{C}_{11}$ aromatics, $(\boldsymbol{\Delta}, \triangle) \mathrm{C}_{11}$ naphtenic-aromatics, $(\bullet, \diamond) \mathrm{C}_{12}{ }^{+}$aromatics, $(\boldsymbol{\nabla}, \nabla) \mathrm{C}_{12}{ }^{+}$naphtenicaromatics, $(\bullet, \circ)$ methyl naphthalene. 


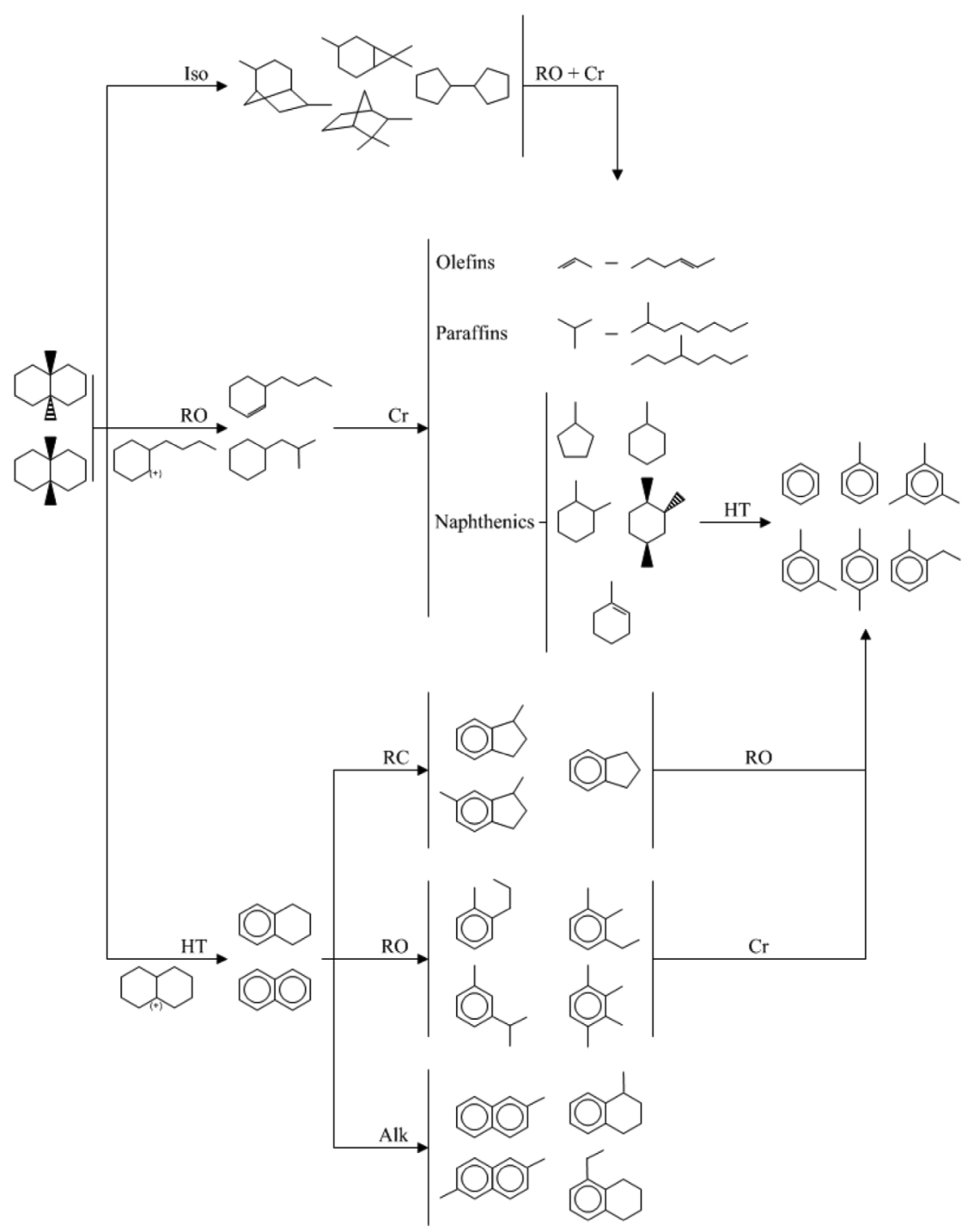

Figure 7. Proposed reaction mechanism. Iso: isomerization; RO: ring opening; HT: hydrogen transfer; Cr: cracking; RC: ring contraction; Alk: alkylation.

could contribute, then, to account for part of the formation of aromatics in the heavy end of gasoline and light end of LCO cuts.

Coke formation is much reduced, as shown by the results at both reaction temperatures over all the catalysts (see, e.g., Table 2). Very low selectivities to coke were observed on USY zeolite, with reported values of $0.0165^{20}$ obtained at $723 \mathrm{~K}$, with a conversion of about $20 \%$.

\section{Conclusions}

The conversion of decalin at high temperatures of 673$723 \mathrm{~K}$ over laboratory deactivated compound FCC catalysts, which only differed in their accessibility properties, is not subjected to diffusion restrictions, reactions proceeding mainly on the $\mathrm{Y}$ zeolite component. Thermal cracking is negligible and coke yield is very low under these conditions.
The product distributions observed allowed formulating a reaction scheme that included isomerization, ring opening and hydrogen transfer occurring simultaneously as the first reactions in the complex network. Isomerization products could be further subjected to cracking and ring opening, while ring opening products could be further subjected to cracking.

The three initial routes contribute to aromatics, although the most direct path would be that of initial hydrogen transfer from decalin to form naphthalene and tetralin, which can be further subjected to ring contraction, ring opening and alkylation reactions to yield different types of indane, aromatic and napthenic-aromatic compounds. Aromatics with the same carbon atoms number as the reactant are prevailing among aromatic products. The most important sources of monoaromatic compounds are ring opening of indane-type or naphtheno-aromatic 
compounds and hydrogen transfer from naphthenic compounds. The increase in temperature favors cracking reactions selectively against isomerization and hydrogen transfer reactions.

The proposed mechanism could contribute to understand part of the mechanisms of formation of aromatics in the heavy end of gasoline and light end of middle distillate commercial cuts.

\section{Acknowledgments}

The authors acknowledge Universidade Federal de Sergipe, Brazil, with financial support from CENPES/ PETROBRAS (Convênio N. 4600286284 da Rede Temática de Desenvolvimento de Catálise), Universidad Nacional del Litoral, Argentina, CAI+D 2009, Proj. 60-294, Agencia Nacional de Promoción Científica y Técnica PICT 2005 14-32930 and Consejo Nacional de Investigaciones Científicas y Técnicas (CONICET) PIP 1257/09.

\section{References}

1. O'Connor, P.; Stud. Surf. Sci. Catal. 2007, 166, 227.

2. Fusco, J. M.; Einsfeldt, M.; Medeiros, J.; Freire, P. S.; Patricio Jr., N.; Tan, M. H.; Ramos, J. G. F.; Torem M. A.; Annals of IV Encuentro Sudamericano de Craqueo Catalítico, Manaus, Brazil, 2000.

3. Schlosser, C. R.; Baptista, R. D.; Brazil, H. Q.; Chamberlain, O.; Pinho, A.; Sandes, E. F.; O'Connor, P.; Torem M. A.; Proceedings of the Akzo Nobel ECO-MAGIC Catalysts Symposium, The Netherlands, 2001.

4. Hakuli, A. K.; Imhof, P.; Kuehler C. W.; Proceedings of the Akzo Nobel ECO-MAGIC Catalysts Symposium, Noordwijk, The Netherlands, 2001.

5. Diesel Fuel. Specifications and Demands for the $21^{\text {st }}$ Century, UOP LLC: Des Plaines, Illinois, 1998.

6. Mota, C. J.; Rawet, R.; Ind. Eng. Chem. Res. 1996, 34, 4326.

7. Dupain, X.; Gamas, E. D.; Madon, R.; Kelkar, C. P.; Makkee, M.; Moulijn, J.A.; Fuel 2003, 82, 1559.

8. Falco, M.; Morgado, E.; Amadeo, N.; Sedran, U.; Appl. Catal., A 2006, 315, 29.
9. O'Connor, P.; Berends, E. M.; US Pat. 6,930,067 2005.

10. de Lasa, H. I.; US Pat. 5,102,628 1992.

11. Passamonti, F.; de la Puente, G.; Sedran, U.; Ind. Eng. Chem. Res. 2004, 43, 1405.

12. Rainer, D. R.; Rautiainen, E.; Nelissen, B.; Imhof, P.; Vadovic, C.; Stud. Surf. Sci. Catal. 2004, 149, 165.

13. Lai, W. C.; Song, C.; Catal. Today 1996, 31, 171.

14. Kubicka, D.; Kumar, N.; Maki-Arvela, P.; Tiitta, M.; Niemi, V.; Salmi, T.; Murzin, D. Y.; J. Catal. 2004, 222, 65.

15. Mostad, H. B.; Riis, T. U.; Ellestad, O. H.; Appl. Catal., A 1990, $58,105$.

16. Morrison, R. T.; Boyd, R. N.; Química Orgánica, $2^{\text {nd }}$ ed.; Fondo Educativo Interamericano S. A. de C.V.: Mexico, 1985.

17. Santikunaporn, M.; Herrera, J. E.; Jongpatiwut, S.; Resasco, D. E.; Alvarez, W. E.; J. Catal. 2004, 228, 100.

18. Sousa-Aguiar, E. F.; Mota, C. J. A.; Murta Valle, M. L.; Pinhel da Silva, M.; Forte da Silva, D.; J. Mol. Catal. A: Chem. 1996, 104, 267.

19. Al-Sabawi, M.; de Lasa, H.; Chem. Eng. Sci. 2010, 65, 626.

20. Corma, A.; Gonzalez-Alfaro, V.; Orchilles, A. V.; J. Catal. 2001, $200,34$.

21. Quintana-Solórzano, R.; Thybaut, J. W.; Marin, G. B.; Appl. Catal., A 2006, 314, 184.

22. de la Puente, G.; Sedran, U.; Appl. Catal., A 1996, 144, 147.

23. Wojciechowski, B. W.; Corma, A.; Catalytic Cracking: Catalysts, Chemistry and Kinetics; Marcel Dekker Inc.: New York, 1986.

24. Chandra Mouli, K.; Sundaramurthy, V.; Dalai, A. K.; Ring, Z.; Appl. Catal., A 2007, 321, 17.

25. Sedran, U.; Catal. Rev. - Sci. Eng. 1994, 36, 405.

26. McVicker, G. B.; Daage, M.; Touvelle, M. S.; Hudson, C. W.; Klein, D. P.; Baird Jr., W. C.; Cook, B. R.; Chen, J. G.; Hantzer, S.; Vaughan, D. E. W.; Ellis, E. S.; Feeley, O. C.; J. Catal. 2002, $210,137$.

27. Santana, R. C.; Do, P. T.; Santikunaporn, M.; Alvarez, W. E.; Taylor, J. D.; Sughrue, E. L.; Resasco, D. E.; Fuel 2006, 85, 643.

Submitted: March 8, 2012

Published online: June 29, 2012 